The Sustainable City XIII 639

\title{
APPLICATION OF TRANSPORTATION BIG DATA TO SUPPORT DECISION-MAKING FOR ARCHITECTURE TEAMS: PROCESSES AND EXPERIENCES FROM TWO CASE STUDIES
}

\author{
LADISLAVA FIALKA SOBKOVÁ, MICHAL ČERTICKÝ \& ŠIMON JIRÁČEK \\ Czech Technical University, Czech Republic
}

\begin{abstract}
Increasing demands on big data and smart solutions are visible in most branches of human activity. This movement is also present in the field of architecture and urban design. To build proper tools and information structures which deliver the required information to architects and urban designers, the further use of big data is necessary. The focus of this paper is the description of how architects use the big data report in the design process of the medium-scale public space renewal projects. We analyzed the usage of big data analysis during the design processes of two public space renewal projects. The Prague Institute of Planning and Development commissioned two pilot studies for Klárov square and Revoluční street, where the big data report was a part of the project bases. The provided report was extracted from the agent-based simulation model of the multimodal mobility of Prague. We combined in this agent-based model the data from mobile phone traces, statistical offices, open street maps, public transport timetables, travel diary surveys, foursquare and cadastral offices. The big data report contains data about residents and passers-by: their quantity, education, financial income, gender, age, marital status, number of children and household members, economic activity, mode of transport and type of activity. We also visualized the spatial distribution of paths and destinations. The experiences of both architecture teams had many common points. They considered the reported sociologic structure of the residents and tourists for the public space design as irrelevant. They would appreciate more detailed information about the transportation flow dependent on time of day. Furthermore, they would expect the ability to test different transportation scenarios in big data-based models as a part of the design process. Both teams would prefer to cooperate with data specialists as direct members of the design team instead of receiving passive reports.

Keywords: big data, public space project, design decision-making, architect, report, tool, agent-based model, case study.
\end{abstract}

\section{INTRODUCTION}

Cities are continually producing large amounts of data. Every change could be recorded as data entry, the data are recorded automatically and routinely [1]. The perception of the cities changed from the geographical description to the set of interactions [2]. Inhabitants using smartphones and computers are instantly producing a strengthening data stream [3]. The spread of smartphones across the Czech population is $63 \%$ and among the young population (16-24 years) $95 \%$ of the population is covered by smartphones[4], the average user of a smartphone has installed 80 apps on their phone and uses close to 40 of them each month [5]. The opportunistic and novel use of how to combine the data obtained for purposes other than why they were collected, are extending the possibilities for managing, using and also designing cities [6]. These data and their further analysis can help cities become better organized, more intelligently developed and more interactive [7]. The cities are becoming plannable in minutes to hours, but big data can still provide valuable input for projects which will transform the city for decades [1]. 
This paper describes the way how the practicing architects solving real projects reflects the outputs of the big data-based models and also shows their demands and expectations from the fields of architecture tools and source information for responsible decision making.

In the first part of this paper we characterize the legal and assigning conditions of both projects. In the next section this paper describes the agent-based model and its data inputs, the provided report and its structure. The result is based on the outcome of interviews with the architects of both projects, which constitutes the main part of the paper.

\section{STATE OF RESEARCH}

Mobile phone trace analyses are used in strategic planning [1], [8], [9] rather than in smallerscale projects. The City of Prague uses mobile phone analysis as one of the source materials for local plans [9].

The datasets collected via mobile phone traces were visualized for the first time during the Venice Biennale in 2006 [10]. Residual mobile phone data are used in the urban context for socio-economic and demographic analysis [11], [12] but they are also applicable in transportation modelling for future scenarios, where they form a data source for activitybased models and agent-based simulations [13], [14]. Mobile phone traces represent a costly input with limited accessibility compared to data collected through crowdsourcing via smartphone applications. Applications for mobility monitoring, such as CO2Go [15] and Carbon Diem [16], are monitoring the mobility of users with the aim of decreasing their carbon footprint. Big data are considered a valid source for transportation simulation models and analytical tools [17], [18]. Content and visual concept have been tested in terms of user friendliness and capacity to provide easily readable information for decision making [18]. The requirements of particular users vary depending on the decision-making process, national legislation, placing conditions and different contexts [19], [20].

\section{METHOD}

The Prague Institute of Planning and Development (hereinafter, IPR Prague) is the body in charge of developing the concept behind the city's architecture, urbanism, development and formation. This organization is funded by the Prague municipal administration with the aim of representing the city in spatial planning matters. IPR Prague launched two pilot studies for the reconstruction of central public spaces in the city - Revoluční street and Klárov square.

The report from the agent-based simulation model of multimodal mobility of Prague, which was based, among other things, on mobile phone traces, was part of the project source materials. From the model, we extracted the socio-economic and demographic factors of the residents of and non-local visitors to the project sites. The report also contained information on the area itself.

This experiment aimed to prove the usability of the structure and content of the transferred information for projects of similar scales. There were just these two case studies to assess the benefits of the report due to the high cost and long timespan of the projects. The cost of providing a single report is EUR 2,000. The Development of the studies took approximately one year due to the number of involved parties in the urban design process.

We conducted interviews with the architects to find out how they used the reports. The interviews had a solid structure of dichotomous questions. We asked the architects for additional wider explanations for each answer provided. The interviewees were talkative so there were situations when they responded to questions before they were asked. The interviewees were senior architects in charge of the projects. 


\section{PROJECT DESCRIPTION}

\subsection{The conceptual study format}

IPR Prague is an organization financed by the capital city of Prague, which revitalizes public spaces using the tools of reconstruction of public spaces. This process begins with the production of a conceptual study. Its proposal primarily stands as a basis for further levels of project documentation and later could be the starting point for decision-making in investment projects for the city, various city organizations, municipal districts, and other involved subjects. The format of said case studies is not defined by the Construction Act, and it is not legislatively binding. The formal degree of commitment is stated by the Prague City Council as the purchaser of the study. It is crucial to define the procedure for discussions with the affected subjects in the area. Conceptual studies are not legally defined project documentations, and therefore the way of handling is also not predefined, which makes it a matter of agreement between all involved parties. It is necessary to establish the entire project prior to the beginning of work with the agreement of all involved parties (Fig. 1). In general, it is necessary to find such ways of designing and consulting which would allow maximal mutual agreement. A clear formulation of such an agreement would enable more fluent discussions about future investment in the area.

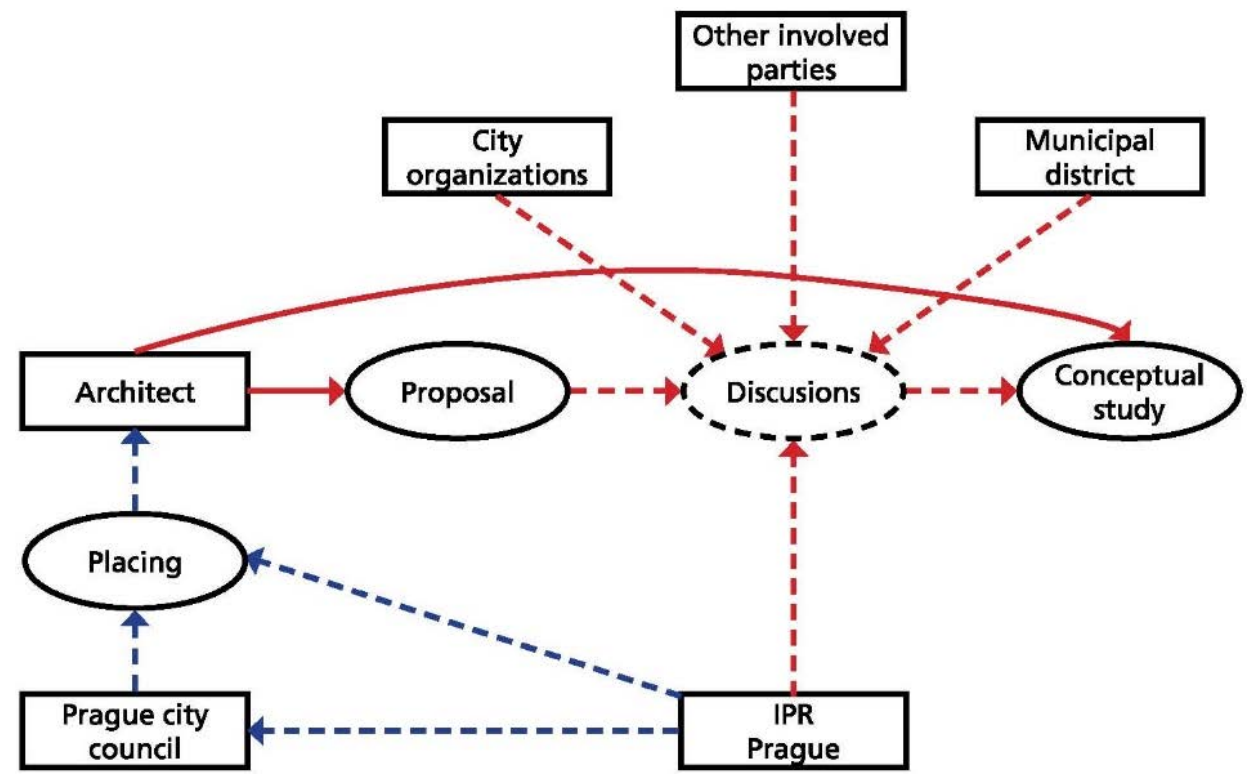

Figure 1: Scheme of the decision-making process.

\subsubsection{Analytical foundation}

Before beginning of work on the design of the conceptual study, IPR Prague will be informed about the analytical foundation of the area, which serves all parties involved but mainly the contractor. This data involves the history of the area, its current state, use, perception and control of the area (Fig. 2). Understanding the complex problematics from the viewpoints of both the users and the operators is the prerequisite for successful design and its handling. 


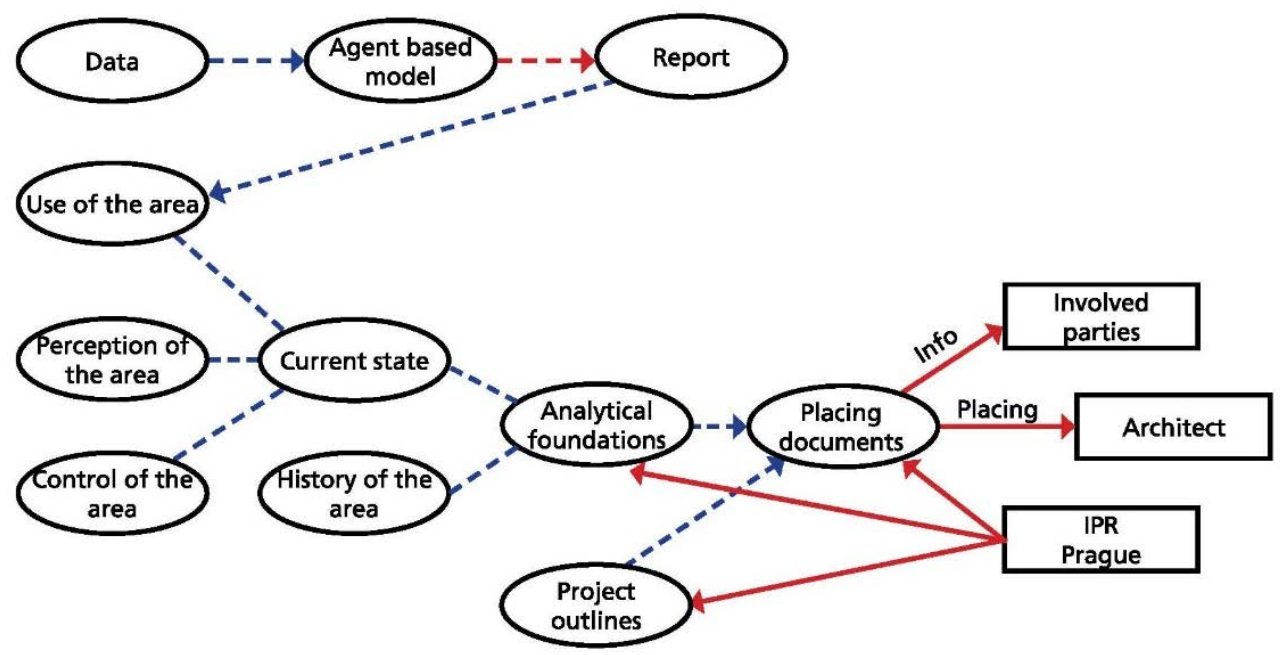

Figure 2: Scheme of the placing documentation.

These are the analytical foundations insured for this conceptual study:

- Historical urban analysis

- Historical development of the location, based on maps

- Urban relations in further context

- Sociological research

- The grouping of tourists in the area

- Pedestrian street transmittance

- The rental value in parterre

- The structure of the land and real estate owners

- Types of establishments in the area

- The traffic research

- Pedestrian movement monitoring

- Transportation and parking policies

- Noise level analysis

- Dendrological research

- Technical infrastructure conducts

- Demographic analysis, analysis of movements and activities of public - report from the agent-based simulation model of multimodal mobility of Prague

\subsubsection{Selection of the contractor}

The processing of the conceptual study is managed by IPR Prague together with a team of external contractors, commonly consisting of architects, landscapers, traffic engineers, and other specialists necessary for the project. The selection of the contractor is ensured by legal tender, either opened or challenged. Conceptual studies of Klárov square and Revoluční street both had a closed selection procedure with five contractors. 


\subsection{Conceptual study: Klárov square}

The examined conceptual study of Klárov square (Fig. 3) is located in the historical centre of Prague in the cadastral district of Lesser Town (Malá Strana). This location is heavily burdened by public transport since it is a crossing point for both tram and metro connections. The area is of great historical importance and since Klárov square directly connects to the Prague Castle complex, it is also heavily exposed to tourism. The layout of the Klárov-Nábřeží Edvarda Beneše intersection is very unclear and has a high concentration of accidents. There is no other intersection in the Czech Republic with a higher frequency of accidents between cyclists and cars.

The improper layout of this intersection was the main reason for the conceptual consideration of this area. IPR Prague began work on the project based on the resolutions of the Prague City Council from 6.6.2017. Within seventeen months a multidisciplinary study was formulated in close collaboration with Studio A69. This study was admitted by all involved parties and later officially confirmed in another resolution on 13 November 2018 [21]. The project was later transmitted to further levels of project documentation from the Department for Transport (Odbor dopravy). The Department for Transport selects a project planner and prepares the documentation for the territorial governances to be discussed, and later executed. During the process, the planners were heavily relying on materials which reflected the development of the area and its significance in the past century. Significant emphasis was also placed on the contemporary use of the area, on the spectrum of users and the issues connected with the transport organization. The entrance to the metro station, placement of the technical infrastructure and the property map set fixed boundaries to the reorganization of the physical space affecting not only the new structure of the area, but also the placement of new vegetation.

The processing of the Conceptual study reached CZK 946,000 excluding VAT (EUR 37,098) Estimated total investment costs for the project are CZK 344,608,000 excluding VAT (EUR 13,514,039).

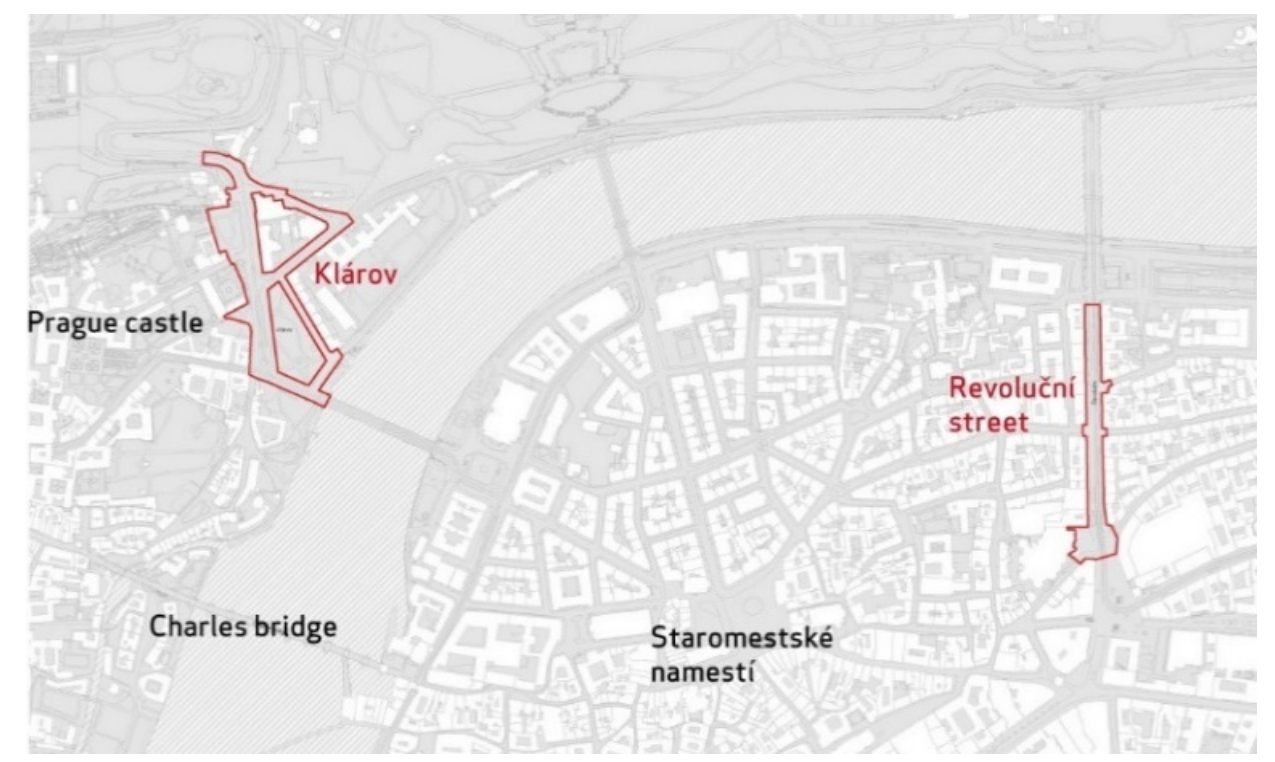

Figure 3: Map of the sites. 


\subsection{Conceptual study: Revoluční street}

Revoluční street is located in the historical centre of Prague (Fig. 3), in the cadastral district of Old Town (Staré město), on what used to be the moat of the Old Town walls since the 13th century. The walls served their purpose until the 12th of February 1784, when the independent Royal city of Prague was established. The modern aspects of the street profile are therefore not the outcome of urban tendencies of the last century, but rather the aftermath of historical evolution. Both tram traffic and personal vehicles are operating on Revoluční street. The dimensions of the street open to road traffic in some areas reach $17 \mathrm{~m}$ over a $20 \mathrm{~m}$ street, strongly limiting pedestrian zones. Due to the absence of car traffic limitations, the area strongly exceeds capacity utilization levels during rush hours. Over 15,000 cars pass through the street on a daily basis. Despite the fact that Revoluční street directly neighbours Republic Square (Náměstí Republiky) with daily counts of over 80,000 pedestrians [22] only about 6,000 [23] people walk through Revoluční Street daily. This is the direct result of the hostile environment with its high traffic intensity and poor state of public space.

This concept study was initiated as a direct response to the panned reconstruction of tram tracks, which brought necessary investments and re-opened the question of the complexity of the area.

The project was formally commissioned based on the resolutions of the Prague City Council from 21 November 2017. The Atelier of Ondřej Císler, consisting of architects, landscapers, and traffic engineers, was chosen in a closed tender. The disputed character of the area led to a number of essential and difficult compromises from all involved parties. (The Prague Public Transport Company/Dopravní podnik - trams, Prague Cycling Commission/Komise pro cyklodopravu and Department for Transport of the Municipal District/Odbor dopravy MČ - cars) Within 10 months an arrangement was reached and commissioned, based on the resolutions of the Prague City Council from 25 September 2018. [24] The Prague Public Transport Company (Dopravní podnik hlavního města Prahy) established the planned completion date of 2024 - seven years from the beginning of work.

The processing of the Conceptual study reached CZK 615,000 excluding VAT (EUR 24.1,7). Estimated total investment costs for the project are CZK 121,109,904 excluding VAT (EUR 4,749,408).

\section{THE AGENT-BASED SIMULATION MODEL OF MULTIMODAL MOBILITY OF PRAGUE}

\subsection{Model description}

The reports were generated by the multi-agent activity-based model of Prague and the Central Bohemian Region [25]. In contrast to traditional four-step demand models [26], which use trips as the fundamental modelling unit, activity-based models employ so-called activities (e.g., work, shop, sleep) and their sequences to represent the transport-related behaviour of the population. Travel demand then occurs due to the necessity of the agents to satisfy their needs through activities performed at different places at different times. These activities are arranged in time and space into sequential (daily) schedules. Trip origins, destinations and times are endogenous outcomes of activity scheduling. The activity-based approach considers individual trips in context and therefore allows the representation of realistic trip chains. The specific model used in this work (as well as similar studies, such as the one published in Fiedler et al. [27]), covers a typical workday in Prague and the surrounding 
Central Bohemian Region. The population of over 1.3 million is modelled by the same number of autonomous, self-interested agents, whose behaviour is influenced by their sociodemographic attributes, current needs, and situational contexts. Individual decisions of the agents are implemented using machine learning methods (neural networks, decision trees, random forests, etc.) and trained using real-world data sets, including census data, travel diaries and other transportation-related surveys. Planned activity schedules are simulated and tuned, and, finally, their temporal, spatial and structural properties are validated against additional historical real-world data (origin-destination matrices and surveys) using the six-step validation framework VALFRAM [28], [29] (Fig. 4).

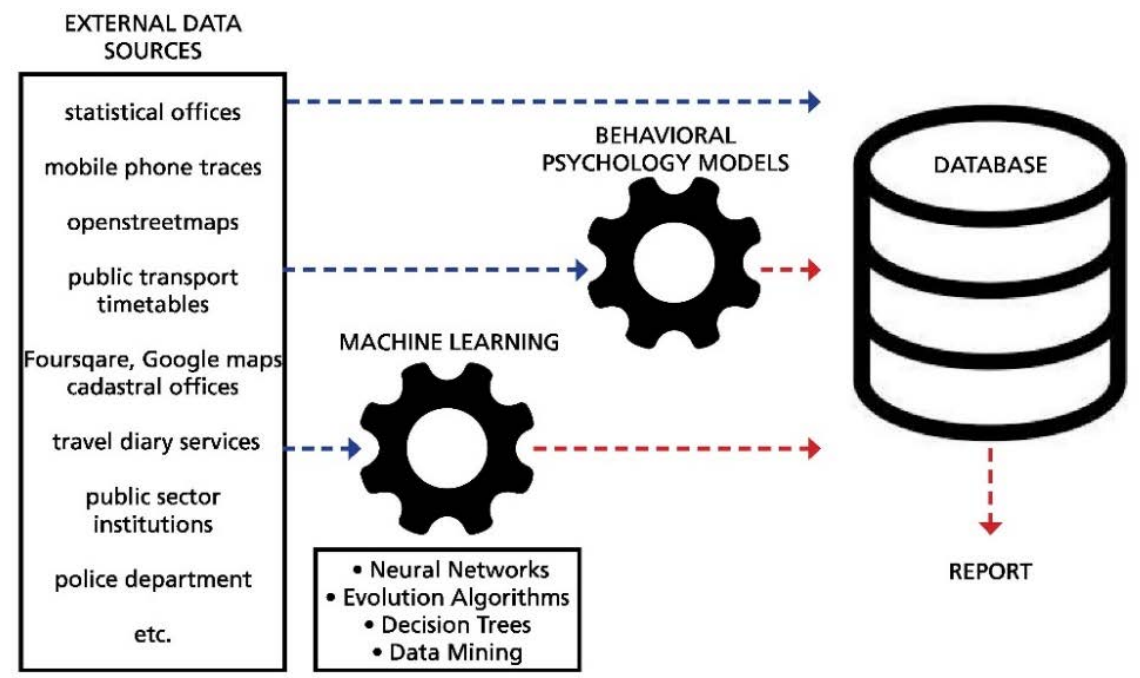

Figure 4: Scheme of the model.

\subsection{Report description}

The report itself is a 40 page PDF document containing the analysis specification, the description of data sources and three sections with the actual results: Sections 1 and 2 focus on local residents of the analyzed area and the non-local passers-by in the area respectively, while the last section contains information about the area itself (not focusing on the population).

More specifically, Sections 1 and 2 contain the following types of the results:

- the statistical distribution of the population by achieved level of education;

- their financial income;

- gender;

- marital status;

- age;

- $\quad$ economic activity (employees, retirees, students, etc.);

- activities performed at the analyzed area;

- mode of transport used to reach the activity location; and,

- number of dependent children and a number of household members. 
Furthermore, Sections 1 and 2 contain the visualizations of the trips of the modelled population and their home and work/school locations.

Section 3 contains the following information about the area itself:

- crime rate in the area;

- noise levels in the area (including visualizations);

- air pollution;

- catchment area visualization (depicts the locations from which people travel to the analyzed area);

- points of interest;

- durations of activities performed in the area;

- nationalities in the area; and,

- households in the area by type/size.

\section{OUTCOME OF INTERVIEWS}

\subsection{Klárov square}

\subsubsection{Work with the report}

The project for Klárov square, which is in the city centre, is more closely connected with the context of the city than a local intervention. The architects believed the local socio-economic conditions to be irrelevant for the project because they intended to design the public space of the square to be accessible and comfortable for everybody. Only a small number of residents live in the area. Thus, passersby were more important in this case. The movement of passers-by was, according to the architects, predictable, so the report didn't bring any surprising or unexpected information.

They considered the content of the report helpful for the intervention into the stabilized residential structure, where the design solution could target the particular local population. In this case the architects would expect a description of the trends in socio-economic aspects (aging of the population, etc.) not just in the addressed area, but also in neighbouring quarters.

\subsubsection{Expectations}

The most important part of the project was the traffic concept - the solution of a double crossroads, where pedestrians meet cars and trams. The concept of the crossroads is crucial for traffic in central Prague. The traffic information about the site - traffic surveys, counting of transport - were highly appreciated by the architects. The architects missed the prediction materials, which were also connected with transportation. They would like to ask what will happen if they would change the traffic arrangement in the wider surrounding. The architects predicted that the Klárov crossroad layout can influence the traffic in an array of $6 \mathrm{~km}$. Big data can be, according to them, helpful in firstly monitoring and secondly predicting of the traffic behaviour.

\subsubsection{Integration of smart solutions}

The architects considered the current accessible tools for transport modelling to be slow, maladjusted and expensive, so they did not use them during the design process. They just estimated the count of cars in a given direction after they applied new traffic solutions.

The concept of Klárov square includes smart solutions - sensors for operating the traffic lights. Integration of other smart solutions is not clear yet as the project is in the early phase. 


\subsection{Revoluční street}

\subsubsection{Work with the report}

The report was used for the confirmation of the architects' opinions, but the decisions about the public space design were based on observation and the site knowledge of the architects. The report presented the main statement of the architects - the domination of pedestrian movement along the street. The architects designed Revoluční street as a public space in the central part of the city. Thus the design must be accessible and friendly for the entire population. The demographic and socio-economic factors are irrelevant in this particular project, as in Klárov square.

The architects would recommend the report for projects in settlements and residential areas, where they find it more appropriate to know the structure of inhabitants

\subsubsection{Structure of the report}

The architects considered part of contained information in the report obvious and easy to estimate. They found the socio-economic graphs too detailed for the given purpose. They believed the initial division of the persons into residents and passersby caused a lack of a comprehensive overview: the provided picture of the location was, according to the architects, fragmented in every observed aspect, and they missed a complete overview of the area.

The report contains detailed information about passersby and residents, but architects missed their temporal distribution. By contrast, they found the "traditional" traffic research of the behaviour of car drivers and pedestrians very useful (Fig. 5) because it brought sharper detail and unexpected facts about the site.
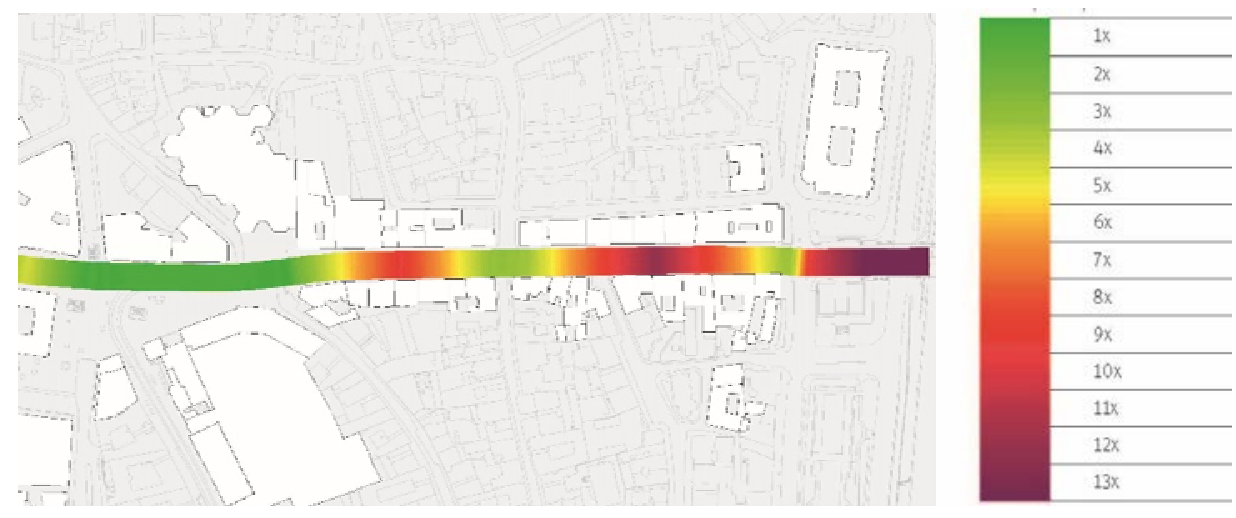

Figure 5: Map of crosswise permeability for pedestrians on Revoluční street

\subsubsection{Expectations}

The architects would have liked to use a tool based on big data to predict traffic behaviour in the location. Existing tools have a limited capacity and high cost. Monitoring the project in all the phases of construction (current state/construction/final state) could assist traffic behaviour modelling. They proposed adding more categories to the report: short stay monitoring, which would be relevant in the central part of the city, and time spent in the solved locality broken into differing categories. The architects note the different needs of the content of the report depending on each project. 


\section{RESULTS}

Both architecture teams would appreciate specific information which is connected to the given location. They would like to ask questions regarding the sites and received responses based on the data from the agent-based model. One of the groups proposed the hiring of an agent-based model specialist as a part of the team, among another experts.

The architects also agreed on the requirement of the traffic modelling tool, based on the real behaviour of car drivers in similar situations, which can be recognized from mobile phone traces [13], [30]. The proposed tool should also integrate the tram network, which provides transportation for $28.6 \%$ of all public transport passengers in Prague [31], and represents a strong player in traffic organization. They would appreciate more detailed information on the local traffic stain.

In the demographic and socio-economic sections of the evaluated reports, both architecture teams found more information than they could use for the given project. The data about the structure of residents and non-local passers-by was not determinative for the public space design process. They also agreed that detailed knowledge of the site and its observation provide more valuable information for them than the report [32]. Independently of the constitution of local and/or passers-by, they designed city centre public spaces suitable for most of the population.

In the socio-demographic information section, one team missed the demographic data on "short time rentals", a contemporary phenomenon affecting the city centre [33].

The third section, "locality description", was unused in decision making because it provided irrelevant information for the project.

\section{DISCUSSION}

\subsection{Type of project}

The public space projects are mostly suited for the public in the sense of the entire population which is passing through the site, unlike projects which are designed for a target group of future users. We composed the report with the aim of providing the architects detailed information about the current users of the space.

The choice of public spaces in city centre was one of the reasons the architects didn't use the report for design decision making. Both teams declared the better employment of the report in residential settlements with a particular structure of inhabitants and non-local passers-by. At the same time, the socio-demographic data is difficult to detect without purchasing the report.

\subsection{Count of respondents}

We had only two groups of respondents. One factor was the timespan of the projects. IPR Prague will firstly have feedback from the architects about the usability of the report before purchasing it for upcoming projects. This is fully understandable considering the cost of the report. Both interviews validated this because it shows the specified demand of experienced users, which could bring changes to the scope and structure of the communicated content. Even though we held interviews with only two groups, we found some overlapping points and new insights in their responses.

\section{CONCLUSION}

For their decision making, the architects required urban data, as Batty defined: with both time and spatial information [1]. The report from the agent-based model contained information 
about the typical day in the locations, but they found its precision to be insufficient. They prefer time division in hours, and they would also appreciate more exact location data at the level of individual streets or directions as it provides conventional traffic research.

The architects required answers for the specific issues of the site. The possibility to access the required information from the agent-based model could be cooperation with the developer of the model on a personal level, instead of receiving the unified report.

The architects also intuited the capability of the agent-based models for the prediction of traffic scenarios, where the data accumulated before, during and after the project realization could be used as the source for upcoming projects.

The socio-demographic section of the reports were described by both teams to be too elaborate with redundant levels of detail.

Both teams agreed they would use the purchased information about the site for projects in public spaces in residential settlements with particular socio-demographic characteristics, where it is difficult to estimate without purchasing the report. Even in this case, they note the need for wider context: the local demographic trends and also information about the socio-demographic tendencies of its surroundings.

\section{ACKNOWLEDGEMENT}

We thank both architecture teams for their participation in the interviews.

\section{REFERENCES}

[1] Batty, M., Big data, smart cities and city planning. Dialogues in Human Geography, 3(3), pp. 274-279, 2013.

[2] Batty, M., The New Science of Cities, MIT Press: Cambridge, MA and London, pp. 15-18, 2017.

[3] Goodchild, M.F., Citizens as sensors: The world of volunteered geography. GeoJournal, 69(4), pp. 211-221, 2007.

[4] Czech Statistical Office (CZSO), Individuals using mobile phone in the Czech Republic, 2018.

www.czso.cz/documents/10180/61508128/0620041823.pdf/62afeb86-2c8f-4b8f9dd2-cd5873ce02a9?version=1.2. Accessed on: 18 Jul. 2019.

[5] App Annie, Monthly average number of apps used and installed - Smartphone users in selected markets, 2017. www.appannie.com/en/insights/market-data/apps-used2017/. Accessed on: 18. Jul. 2019.

[6] Ratti, C. \& Claudel, M., The City of Tomorrow: Sensors, Networks, Hackers, and the Future of Urban Life, Yale University Press: New Haven and London, pp. 28-30, 2016.

[7] Chen, M., Mao, S., Zhang, Y. \& Leung, V.C.M., Big Data Related Technologies, Challenges and Future Prospects, Springer: Cham, Heidelberg, New York, Dordrecht and London, pp. 74-76, 2014.

[8] Novobilský, J. \& Novák, J., Inovativní přístupy k zachycení přítomného obyvatelstva: Data mobilních operátorů. Urbanismus a územní rozvoj, XVI, pp. 15-19, 2013.

[9] Čtyroký, J., Section Director of Spatial Information Section, Prague Institute of Planning and Development, Prague, 2017.

[10] Calabrese, F., Colonna, M., Lovisolo, P., Parata, D. \& Ratti, C., Real-time urban monitoring using cell phones: A case study in Rome. IEEE Transactions Intelligent Transportation Systems, 12(1), pp. 141-151, 2011. 
[11] Cesare, N., Lee, H., McCormick, T., Spiro, E. \& Zagheni, E., Promises and pitfalls of using digital traces for demographic research. Demography, 55(5), pp. 1979-1999, 2018.

[12] Cottineau, C. \& Vanhoof, M., Mobile phone indicators and their relation to the organisation of cities. ISPRS International Journal of Geo-Information, 8(1), p. 19, 2019.

[13] Anda, C., Erath, A. \& Fourie, P.J., Transport modelling in the age of big data. International Journal of Urban Sciences, 21(1), pp. 19-42, 2017.

[14] Leng, Y., Noriega, A., Pentland, A.S., Winder, I., Lutz, N., \& Alonso, L., Analysis of tourism dynamics and special events through mobile phone metadata. Proceedings of Data for Good Exchange (D4GX), 2016.

[15] CO2Go, http://senseable.mit.edu/co2go/. Accessed on: 18 Jul. 2019.

[16] Shin, D. et al., Urban sensing: Using smartphones for transportation mode classification. Computers, Environment and Urban Systems, 53, pp. 76-86, 2014.

[17] Croce, A.I., Musolino, G., Rindone, C. \& Vitetta, A., Transport system models and big data: Zoning and graph building with traditional surveys, FCD and GIS. International Journal of Geo-Information, 8(4), p. 187, 2019.

[18] Popelka, S. et al., User evaluation of map-based visual analytic tools. International Journal of Geo-Information, 8(8), p. 363, 2019.

[19] Cascetta, E., Cartenì, A., Pagliara, F. \& Montanino, M., A new look at planning and designing transportation systems: A decision-making model based on cognitive rationality, stakeholder engagement and quantitative methods. Transport Policy, 38, pp. 27-39, 2015.

[20] Musolino, G., Rindone, C., Polimeni, A. \& Vitteta, A., Planning urban distribution center location with variable restocking demand scenarios: General methodology and testing in a medium-size town. Transport Policy, 80, pp. 157-166, 2019.

[21] A69 Architects, Conceptual study of Klárov locality, Prague, 2018.

[22] O2 Geodata, Visit rate measurements of Hradební korzo in Prague, using the $\mathrm{O} 2$ Geodata service and processing of the statistical output, Prague, 2019.

[23] Prague Institute of Planning and Development, Pedestrian movement monitoring at the area of Hradební korzo, 2018.

[24] Aoc Architects Inc., Conceptual study of Revoluční Street, Prague, 2018.

[25] Čertický, M., Drchal, J., Cuchý, M. \& Jakob, M., Fully agent-based simulation model of multimodal mobility in European cities. International Conference on Models and Technologies for Intelligent Transportation Systems (MT-ITS), pp. 229-236, 2015.

[26] Hensher, D.A. \& Button, K.J., Handbook of Transport Modeling, Emerald Group, 2007.

[27] Fiedler, D., Čertický, M., Alonso-Mora, J. \& Č́p, J., The Impact of ridesharing in mobility-on-demand systems: Simulation case study in Prague. 21st IEEE International Conference on Intelligent Transportation Systems (ITSC 2018), 2018.

[28] Drchal, J., Čertický, M. \& Jakob, M., VALFRAM: Validation framework for activitybased models. Journal of Artificial Societies and Social Simulation, 19(3), pp. 1-5, 2016.

[29] Drchal, J., Čertický, M. \& Jakob, M., Data driven validation framework for multiagent activity-based models. International Workshop on Multi-Agent Systems and Agent-Based Simulation, Springer, pp. 55-67, 2015.

[30] Steenbruggen, J., Borzacchiello, M.T., Nijkamp, P. \& Scholten, H., Mobile phone data from GSM networks for traffic parameter and urban spatial pattern assessment: A review of applications and opportunities. GeoJournal, 78, pp. 223-243, 2013. 
[31] Znáte Prahu? Město v mapách, grafech a číslech, The Prague Institute of Planning and Development (IPR Praha). www.iprpraha.cz/uploads/assets/dokumenty/obecne/ znate_prahu_e.pdf. Accessed on: 17 Jul. 2019.

[32] Gehl, J. \& Svarre, B., How to Study Public Life, Island Press: Washington, DC, pp. 56, 2013.

[33] Oskam, J. \& Boswijk, A., Airbnb: The future of networked hospitality businesses. Journal of Tourism Futures, 2(1), pp. 22-42, 2016. 